Maria Célia Dias de Castro*

Maria Suelí de Aguiar**

\title{
ResUMO
}

Neste trabalho, partimos da teoria clássica sobre a natureza dos nomes e procuramos discorrer historiograficamente acerca dos pensamentos filosóficos que iniciaram esses estudos, desde os platônicos, na obra "Crátilo", passando pela discussão de Whitney até os sempre atuais estudos de Saussure, autores que discutem se os nomes são formados por motivação natural (Physei) ou por convenção (Thesei). Relacionamos essa discussão aos nomes toponímicos dos municípios do Estado do Maranhão, em que procuramos inter-relacionar a influência da estrutura formal do signo linguístico com o objeto que ele representa no processo de nomeação.

PALAVRAS-CHAVE: nomes, justeza natural, convenção, toponímia maranhense.

"O conhecimento dos nomes não é negócio de importância somenos... Mas, de muito bom grado, me disponho a investigar o assunto juntamente contigo e Crátilo".

(Platão)

INTRODUÇÃO

As reflexões que aqui expomos procedem de uma visão em que consideramos a língua como um sistema de signos utilizado, principalmente, como instrumento da interação entre os sujeitos falantes. Mediante esse sistema, os sujeitos expressam seus desejos, seus sentimentos, suas histórias; descrevem seres, lugares, eventos,

* Doutoranda do Programa de Pós-Graduação em Letras e Linguística - Área de Estudos Linguísticos - da Universidade Federal de Goiás, Goiânia-GO.

E-mail: celialeitecastro@hotmail.com

** Professora do Programa de Pós-Graduação em Letras e Linguística da Universidade Federal de Goiás, Goiânia-GO.

E-mail: aguiar@letras.ufg.br 
ações, atividades e estados conceptualizados como entidades a partir de aspectos culturais (gerais e mais específicos), sociais e históricos. $\mathrm{Ou}$ seja, o sujeito se situa, se organiza, se expressa por meio da língua e se utiliza de elementos que são percebidos e descritos por meio de signos - os nomes -, cuja origem é marcada pelo processo de constituição da cultura do homem, que o contextualiza espacial, histórica e socialmente.

A discussão acerca da origem dos nomes é algo inacabado e que está longe de se esgotar. Desde os tempos clássicos, com Platão, vem-se discorrendo sobre esse assunto e chegamos aos tempos atuais com plena força exatamente por não existirem até agora estudos que aprofundassem o suficiente sobre o tema. Muitos autores apresentam suas posições diante das discussões, sem, no entanto, atualizarem a abordagem de maneira a preencher as principais lacunas que vêm instigando os estudiosos do signo linguístico.

Este trabalho está dividido em quatro partes. Na primeira, fazemos uma reflexão de base historiográfica, em que salientamos os trabalhos clássicos de Platão, no diálogo "Crátilo"; de Whitney, no ensaio Physei or Thesei: natural or convencional?; e de Saussure, na clássica obra Curso de Linguística Geral (doravante Curso). Nessas obras, os autores discorrem acerca da natureza dos nomes. Na segunda parte, focalizamos a arbitrariedade do signo. Logo a seguir, analisamos os nomes próprios toponímicos maranhenses, os quais apresentam uma relação sociocultural e histórica com as entidades que representam. Por último, nas considerações finais, fazemos algumas observações inferidas a partir das reflexões anteriores.

UM POUCO DE HISTORIOGRAFIA E DE TEORIA DA LÍNGUA(GEM)

\section{O Crátilo}

A obra Os diálogos de Platão, cuja primeira tradução do grego para o português é do professor Carlos Alberto Nunes, da Universidade Federal do Pará, envolve um conjunto de catorze volumes. Há também um livro introdutório, denominado Marginalia platônica, segundo o qual a obra platônica foi dividida cronologicamente em três grupos. No primeiro, estão incluídos os diálogos considerados do período em 
que Platão mais recebeu influência de Sócrates (o volume I) que são: "Apologia”, "Critão", "Laquete", "Cármides", "Líside", "Eutífrone". No segundo, estão as obras relacionadas ao período considerado mediano de Platão (os volumes II e III): "Protágoras", "Górgias", "Iaô", "Menão", "Menexeno", "Eutidemo"; e IV a VIII, nos quais se incluem as cartas e os diálogos de maior penetração: "O Banquete", "Fedão", "Fedro", e "A República" e ainda "O primeiro Alcebíades", "O segundo Alcebíades", "Hípiass Menor", e "Hípias Maior". O terceiro, em que estão obras de suma importância, inclui o volume IX: "Teeteto" e "Crátilo"; o volume X: "Parmênides" e "Filebo"; o volume XI inclui: "Sofista" e "Político"; o volume XII: "Timeu" e "Crítias"; e os volumes XIII e XIV: "Leis" e "A República".

Para este trabalho interessa-nos, sobremaneira, a obra "Crátilo" ou "Sobre a justeza dos nomes", incluída no volume IX. Esta obra é uma famosa e remota fonte dos estudos da linguagem, um dos diálogos de Platão mais polêmicos até a atualidade, em que se registram os pensamentos mais antigos acerca da língua e da linguagem. O diálogo envolve três personagens: Hermógenes, Crátilo e Sócrates e abre uma discussão acerca da justeza dos nomes. Hermógenes defende que o conteúdo e a forma da linguagem ligam-se por "convenção" ou "acordo", enquanto Crátilo defende que essa relação se dá por "justeza natural" dos nomes à coisa que representa. Sócrates, por meio da maiêutica, ${ }^{1}$ questiona os dois interlocutores para poder chegar a uma conclusão.

Neste artigo, transcrevemos os excertos que mais nos pareceram significativos no que diz respeito à natureza dos nomes, uma vez que esse assunto tem uma relação direta com os nomes próprios toponímicos.

\section{Episódio 1: Diálogo de Sócrates com Hermógenes}

Hermógenes - Sócrates, o nosso Crátilo sustenta que cada coisa tem por natureza um nome apropriado e que não se trata da denominação que alguns homens convencionaram dar-lhes [...], mas que, por natureza, têm certo sentido, sempre o mesmo [...] o que pensas a respeito da exata aplicação dos nomes [...]. (p. 119)

[Hermógenes inicia o terceiro parágrafo do diálogo contestando a posição do personagem Crátilo e questionando a tese naturalista.] 
Hermógenes - [...] Para mim, seja qual for o nome que se dê a uma determinada coisa, esse é o nome certo; e mais: se substituirmos esse nome por outro, vindo a cair em desuso o primitivo, o nome não é menos certo do que o primeiro. Assim, costumamos mudar o nome de nossos escravos, e a nova designação não é menos acertada do que a primitiva. Nenhum nome é dado por natureza a qualquer coisa, mas pela lei e o costume dos que se habituaram a chamá-la dessa maneira. (p. 120)

[Hermógenes expõe a sua teoria, em que defende que os nomes são atribuídos convencionalmente.]

Sócrates - Logo, é possivel dizer por meio da palavra o que é e o que não é. (p. 121)

[Hermógenes afirma que o nome é a menor parte da proposição. Se o nome é verdadeiro, a proposição também o será; se não o for, a proposição não o será. Há, portanto, uma correlação entre o nome e a proposição para se considerar algo verdadeiro ou falso.]

Sócrates - Logo, nomear, também é ação, uma vez que falar é uma espécie de ação, com relação a certas coisas. (p. 124)

[Já se aponta a teoria que propõe que falar é uma ação e dar nome é parte do ato de falar.]

Sócrates - O nome, por conseguinte, é instrumento para informar a respeito das coisas e para separá-las, tal como a lançadeira separa os fios da tela. (p. 126)

[Apresentam-se os nomes como funcionais e referenciais para o sujeito falante.]

Sócrates - Por conseguinte, Hermógenes, nem todos os homens têm capacidade para impor nomes, mas apenas o fazedor de nomes, $e$ esse, ao que tudo indica, é o legislador, de todos os artistas o mais raro. (p. 127)

[Aquele que nomeia, o fazedor de nomes, é um legislador; o ato de nomear é uma arte.]

Sócrates - Logo, meu excelente amigo, o nosso legislador deverá saber formar com os sons e as silabas o nome por natureza apropriado para cada objeto, compondo todos os nomes e aplicando-os com os olhos sempre fixos no que é o nome em si, caso queira ser tido na conta de verdadeiro criador de nomes. [...]. (p. 128) 
[Os sons e as sílabas constituem a base para compor os nomes apropriados aos objetos que nomeiam; ou seja, há signos distintos para objetos distintos.]

Sócrates - Do mesmo modo julgarás o legislador, tanto daqui como dos bárbaros; uma vez que ele reproduz a ideia do nome, a propriedade para cada coisa, pouco importando as sílabas de que se valha, em nada deverá ser considerado inferior, quer seja daqui, quer de qualquer outra região. (p. 128)

[As diferenças regionais de sons, quer sejam letras ou sílabas que formam o nome para representar uma ideia, não são relevantes base sociolinguística.]

Sócrates - [...] os nomes, por natureza, têm uma certa justeza e que nem toda a gente sabe como designar convenientemente as coisas. (p. 130)

[O filósofo demonstra que não há um limite que estabelece a fronteira entre a justeza natural e a convenção.]

Sócrates - [...] Como sabes, designamos as letras por nomes que não são elas próprias, com exceção das quatro vogais: é, y, o, ô. As demais vogais ou consoantes, formamos-lhes os nomes com o acréscimo de outras letras. Mas, desde que incluamos apenas o valor da letra claramente expresso, é certo designá-la por determinado nome, que no-la dará a conhecer. Tomemos como exemplo o beta; como vês, a adição das letras ê, $t, a$, não causa nenhum transtorno e não impede que a natureza dessa letra seja revelada pelo nome inteiro, conforme intenção do legislador [...]. (p. 133)

[O filósofo menciona que uma pequena alteração por causa de letras e sílabas nem sempre modifica o valor intrínseco do nome, se exprimir a mesma coisa. Logo em seguida a esse parágrafo, Sócrates faz uma longa descrição acerca dos sons, apoiando-se em uma base fonético-fonológica acerca do que seriam as vogais e as consoantes, e versa acerca do significado de certos nomes, em que, para poder explicá-los, se atém à etimologia deles.]

Sócrates - [...] Há muita probabilidade de atinarmos com o sentido exato dos vocábulos nos nomes relacionados com as coisas eternas e a natureza, pois nesse domínio deve ter havido bastante critério na escolha, sendo possivel até que uns tantos houvessem sido formados por algum poder divino, superior aos homens. (p. 137) 
[Verificamos, nesta assertiva, ao se referir à exatidão inerente aos nomes que se relacionam à natureza, que os topônimos observados em nosso estudo expressam significados peculiares. Na página 178, Platão propõe que determinados nomes são atribuídos com mais propriedade do que outros.]

Sócrates - Foi o que se deu, segundo penso, com a palavra "homem". Uma sentença virou substantivo pela supressão da letra "a" e a acentuação da última sílaba. (p. 140)

[A mudança de classe dos nomes pode decorrer de uma alteração de som e/ou acento.]

Sócrates - [...] Qual te parece ter sido a causa de possuir cada coisa um nome? Não foi o princípio que impôs nomes? (p. 162)

[O pensamento é tido como princípio para que cada coisa fosse nomeada como obra da inteligência e do entendimento.]

Sócrates - Quer parecer-me que o vocábulo ónoma (nome) é uma proposição concentrada, que afirma a existência do ser (ón) que investigamos. (p. 167)

[A etimologia da palavra "nome" abarca uma análise empírica e um exercício metafísico e ontológico.]

Sócrates - [...] Sempre, porém, que chegarmos a uma palavra não formada de outros nomes, temos o direito de concluir que se trata de elemento primitivo, não explicável por nenhum outro (p. 169)

[Numa análise profunda, o filósofo deduz acerca da justeza dos nomes primitivos]

Sócrates - Que só há um princípio aplicável a todos nomes, do primeiro ao último, e que nenhum nome, como tal, difere de outro nome [...]. (p. 169)

[O filósofo afirma que todos os nomes, por serem da mesma natureza, não se diferem.]

Sócrates - O nome, portanto, como parece, é a imitação vocal da coisa imitada, indicando quem imita, por meio da voz, aquilo mesmo que imita. (p. 170)

[A fala é considerada um processo individual.]

Sócrates - [...] não te parece que cada coisa tem sua essência própria, tal como cor e o mais que acima enumeramos? E a cor, 
também, para começar, e a voz não têm também sua essência, assim como tudo o mais que merece a designação de ser? (p. 171)

[Todo ser tem sua essência.]

Sócrates - [...] Se fosse possível imitar isso mesmo, a saber, a essência das coisas, por meio de letras e de sílabas, não se nos tornaria patente a sua natureza? [...]. (p. 171)

[Sobre a natureza do nome e a imitação da essência das coisas.]

Sócrates - [...] Depois de tudo classificado, será preciso considerar as coisas que terão de receber nome para vermos se entre elas há formas a que todas possam ser reduzidas, como se deu com as letras, e que nos permitam conhecer sua natureza [...] teremos de saber agrupar e relacionar as coisas conforme sua semelhança, seja aproximando uma de outra, seja misturando várias [...]. Criaremos a linguagem por meio da arte de nomear ou de falar, ou que outro nome tenha. (p. 172)

[Os nomes comuns para os seres são classificados como pertencentes a uma mesma categoria gramatical do léxico - a tipologia.]

Sócrates - [...] E assim procedeu o legislador em tudo o mais, reduzindo todas as coisas a letras e sílabas e criando para cada ser um sinal e nome apropriados, para formar por imitação os demais nomes, a partir desses elementos primordiais [...]. (p. 176)

[Como o legislador e filósofo é dialético, conhece a essência das coisas por meio da estruturação da linguagem.]

Sócrates - [...] Não admites que uma coisa é o nome, e outra o objeto cujo nome ele é? (p. 179)

[O filósofo diferencia o nome da coisa que ele representa.]

Sócrates - E o que imita a essência das coisas por meio de sílabas e das letras? [...] esse é o nome certo, mas se omitir alguma coisa ou acrescentar um tantinho, o resultado será também uma imagem, porém não bonita, de forma que alguns nomes ficarão bem formados, e outros, o contrário disso. (p. 181-182)

[O nome é uma imitação verdadeira, mas não absolutamente exata, da coisa; mesmo que lhe seja acrescentado ou subtraído algo, ele continua sendo imagem da coisa e permanece nomeando, conforme a assertiva da p. 183.]. 


\section{Episódio 2: Diálogo de Sócrates com Crátilo}

Sócrates - Mas, se as palavras primitivas têm que ser representação de alguma coisa, conheces processo melhor de atingir essafinalidade, a não ser deixando-as tão semelhantes quanto possivel ao que elas tenham de representar? Ou esposas, de preferência, o modo de ver de Hermógenes e de muitos outros, que afirmam não passarem os nomes de convenção e que só representam alguma coisa para os que convencionaram formá-los depois de terem o conhecimento dessa coisa, baseados precisamente na convenção, a justa formação dos nomes, e que é de todo indiferente manter a convenção, tal como foi estabelecida, ou admitir outra inteiramente oposta, para dar o nome de grande ao que hoje denominamos pequeno e o de pequeno ao que chamamos grande? [...]. (p. 184-185)

[Ao dialogar com Crátilo, Sócrates utiliza-se de perspicácia para chegar ao raciocínio de que o nome é estabelecido convencionalmente.]

Sócrates -E por falar em costume, achas que disseste algo diferente de convenção? Para ti, costume não quer dizer que, quando eu pronuncio aquela palavra, imagino o que estou falando e tu reconheces que estou pensando justamente naquilo? [...]. (p. 186)

[Para Sócrates, o costume une, liga, relaciona as coisas e os objetos dentro de uma determinada comunidade cultural e de fala - é isto que faz com que os falantes de uma mesma língua se entendam.]

Sócrates - [...] reduzindo-se para ti a justeza da aplicação dos nomes a pura convenção, uma vez que tanto servem para representar os objetos as letras semelhantes como as dessemelhantes, desde que o hábito e a convenção as legitimam? Mas, ainda mesmo que o costume não seja convenção, não é certo dizer que a representação se firma na semelhança. É no costume, pois este, como já vimos, consegue representar tanto por meio do semelhante quanto do dessemelhante. [...] forçoso nos será concluir que a convenção e o costume contribuem igualmente para exprimir o que temos no pensamento, no instante que falamos1. (p. 186-187)

[O filósofo ressalta o hábito e a convenção como formas para a legitimação dos nomes, os quais exprimem o que temos no pensamento.]

Sócrates - [...] Basta-nos termos chegado à conclusão de que não é por meio de seus nomes que devemos procurar conhecer ou 
estudar as coisas, mas, de preferência, por meio delas próprias. (p. 192)

[Por fim, conclui, a importância de conhecermos as coisas por elas mesmas e não somente pelo nome.].

Para Hermógenes - baseado na tese de Protágoras (NunEs, 1973) -, a origem e a natureza dos nomes dependem de um acordo social. Ele, induzido dialeticamente por seu interlocutor, concorda que essa existência se dá por convenção. Quanto a Crátilo, cuja tese foi rejeitada, parece concordar que não há realmente um limite preciso entre uma existência natural ou convencional para os nomes. Portanto, o texto se define por apresentar duas teorias básicas. A primeira, a teoria convencionalista, em que Hermógenes defende que qualquer homem pode mudar os nomes das coisas, da mesma forma que os senhores mudam os nomes dos seus escravos. A segunda, a teoria naturalista, em que Crátilo defende que o nome do objeto seria o mesmo para todos os homens e em todas as línguas. Além das acima citadas, uma teoria básica é a da existência de um signo linguístico distinto para cada objeto distinto. Outra: a palavra é apresentada como forma básica da língua; a palavra em si é o nome (substantivo, adjetivo e o verbo) e, por meio dela, é possível dizer o que é e o que não é. É certo que esse tratado de linguagem aborda inúmeros temas que dão margem a diversas novas teorias para o conhecimento da linguagem.

\section{Whitney}

Em meio à rica produção de livros, de publicações em revistas e jornais especializados, destaca-se o tratado Physei or Thesei: natural or convencional?, de Whitney, em que ele considera a questão - já abordada pelos gregos - da existência dos nomes, se por "natureza" ou por "convenção". A despeito de seu interesse histórico, essa questão ainda não foi resolvida, mesmo com todo o progresso já alcançado pela ciência linguística.

Nessa obra, Whitney argumenta que essa polaridade pode ser não muito mais do que uma questão de divergência de ponto de vista ou de um diferente entendimento do significado dos termos usados. Para ele, essa questão, embora ainda tão discutida, é pacífica para a maioria dos 
estudiosos e dos seres humanos, pois eles têm consciência da existência de outros nomes para as coisas que eles usam. Esses nomes são meros apelidos ou alcunhas, pois só as próprias coisas é que são reais.

Whitney conclui que há diversos nomes, semelhantes ou diferentes, para as mesmas coisas nas diversas línguas do mundo, e isso faz com que em algumas eles possam ter mais características de "justeza natural" do que em outras, de acordo com as circunstâncias, com os aspectos educacionais e com o ambiente comunitário. $\mathrm{O}$ autor apresenta um exemplo básico para comprovar a ausência de "justeza natural" dos nomes, o processo pelo qual o indivíduo adquire sua língua materna. Os seres humanos, constituídos normalmente numa comunidade, têm uma faculdade linguística que os torna capazes de aprender e falar, ao adquirirem os signos particulares dessa comunidade, as ideias correspondentes e os métodos de uso estabelecidos e utilizados convencionalmente na comunidade em que nasceram.

Em nenhum lugar da conhecida história do desenvolvimento da linguagem houve qualquer vestígio da dominação do som pelo significado, ou do significado pelo som. De qualquer jeito não há razões, num conjunto de razões observáveis, para que as coisas sejam chamadas como elas são. Elas têm razões fundamentadas, não numa conexão natural, mas em associações previamente formadas, em convenções já estabelecidas. (WHITNEY, 1971 [1871], p. 123-124)²

Whitney contesta o fato de as palavras onomatopaicas serem consideradas como de "justeza natural”. Ao justificar sua posição, caracteriza esses signos como construídos com sugestividade imediata imposta pela natureza da coisa significada e do instrumento empregado para significá-la. Para ele, esses signos imitativos não são de todo primitivos; eles podem ser criados ou ter sua forma modificada. Afirma categoricamente que não há em inglês nenhum nome de coisa por "justeza natural". Esses nomes seriam resultantes de convenção e, para representar as emoções, os seres humanos apresentariam os elementos de forma mais ou menos semelhante: detectam quando outros seres de diferentes raças e línguas estão com raiva, alegres, ou sentindo dores. Isso, entretanto, é diferente para os signos que representam as ideias: as línguas e as palavras são ininteligíveis para aqueles que não as conhecem. Segundo Whitney, há uma grande variedade de expressões da mesma 
ideia em diferentes línguas, uma grande diversidade de expressões para uma mesma ideia e uma grande variedade de significados para as famílias de palavras.

Para Whitney, a criança aprende signos convencionais e arbitrários para as coisas de acordo com o que a comunidade usa e está sujeita a essas mesmas restrições ao propor um nome para um novo objeto cultural: "Mas o único princípio sublinhado é que a nova designação seja obtida onde, de acordo com os hábitos de linguagem existentes, ela possa ser encontrada de modo mais conveniente" (p. 124).

Whitney ressalta ainda a importância do estudo etimológico das palavras, para verificar o surgimento e a modificação delas no curso da história da língua, ou seja, todas as conexões etimológicas. Os falantes, porém, não se dão conta dessas conexões posto que, para eles, a palavra significa a própria coisa. A língua está, pois, inserida num conjunto de saberes que o homem tem recebido de seus predecessores e a que tem acrescentado modificações, como nas demais áreas do conhecimento humano. Whitney salienta, no entanto, que essas condições históricas, tais quais as condições atuais, nada evidenciam acerca da existência de "justeza natural" dos nomes (physei), nem esses princípios são retomados com esse fim. Na verdade, ele chama a atenção para que reconheçamos o impulso para a comunicação como uma força primária e ativa para a produção da fala, bem como para o fato de que o homem fala com o intuito de tornar seus sentimentos e pensamentos conhecidos pelos que o cercam. Para esse autor, certas expressões impulsivas de sons produzidos como sinais (intuitivos) de sentimentos, emoções, não são da natureza da linguagem humana, mas somente sugestão, uma preparação. Ele conclui:

Nossa conclusão, portanto, é a de que não há sentido próprio em que o nomes das coisas possam ser ditos de existência "natural", não somente agora e através dos anos de registro da fala; mas, retomando esse assunto desde sua origem, cada nome tem sido o resultado de um ato "convencional" de atribuição humana. (p. 131, aspas nossas)

Para Whitney, falar é, de certa maneira, natural, e essa natureza também consiste nas circunstâncias que envolvem a natureza individual do homem, como, por exemplo, viver em casas, vestir roupas, utilizar 
instrumentos, formar sociedade, estabelecer costumes etc. Portanto, a arbitrariedade dos nomes não significa que qualquer indivíduo pode sair por aí nomeando à vontade qualquer ideia que selecionar, pois essas mudanças só ocorrem depois de serem aceitas pela comunidade. Dessa forma, o indivíduo não tem, sozinho, o poder de modificar a língua, pois suas forças de conservação atuam contra esse processo e estabelecem limites para essas mudanças. Assim sendo, percebemos que esses postulados são uma continuidade da teoria apresentada na obra de Platão já analisada, o que também ocorre com Saussure, como veremos a seguir.

Saussure

O Curso é uma coletânea das aulas ministradas por Saussure e escritas por Charles Bally e Albert Sechehaye, com a colaboração de Albert Riedlinger. Essa obra traz em si muitos pensamentos de autores que o precederam e foram geradores de férteis pensamentos para as teorias linguísticas, tais como Platão, Humboldt e Whitney. ${ }^{3}$ No entanto, Saussure soube desenvolver esses conhecimentos anteriores de forma a torná-los mais compreensíveis e deu-lhes uma estrutura metodológica, o que tornou o Curso um dos principais instrumentos de análise em todas as línguas para os estudos estruturalistas e pós-estruturalistas. É nessa obra que ele lexicaliza os conceitos linguísticos, sistematizaos e organiza-os. ${ }^{4}$ As noções de estrutura já haviam sido apresentadas desde Platão, mas é em o Curso que propõe um modelo metodológico, embora não o desenvolva plenamente como o fazem os seus sucessores. A obra é célebre para as ciências da linguagem, principalmente pela cientificidade, por servir de instrumento para análises estruturais e por postular o estudo da língua no qual ela tem um fim em si mesma. Para Saussure, a língua dá forma ao pensamento, ou seja, a língua é forma, é imanência, é o principal meio de manifestação da linguagem e o objeto da Linguística.

Dizer que Saussure trouxe grandes contribuições para a Linguística é tautológico. Mas sempre vale a pena relembrar que é ele quem define metodológica e claramente a natureza do signo linguístico e do objeto da Linguística; esclarece sobre a Linguística da língua e a Linguística da fala, bem como sobre os elementos internos e externos 
da língua. Podemos afirmar que a principal contribuição de Saussure para essa disciplina foi postular os conceitos - muitos deles implícitos, como já dissemos, em autores como Platão, Humboldt e Whitney "língua e fala", "signo linguístico", "arbitrariedade e caráter linear", "sincronia e diacronia", "forma e substância", "paradigma e sintagma", "significante e significado".

No que diz respeito à relação do pensamento com a inteligência, com a linguagem, com a língua e com a fala, Saussure concebe a linguagem como anterior ao pensamento e este como anterior à linguagem. Por sua vez, a linguagem é anterior à língua, e esta é anterior à fala. Ele define a inteligência como uma capacidade do pensamento, a linguagem como uma capacidade inata de aprender uma língua e a língua como a norma social para a manifestação da linguagem, esta tanto social quanto individual.

No início do sexto capítulo do Curso, Saussure declara que o objeto concreto de seu estudo são as línguas e sugere aos linguistas que as conheçam em maior número possível para delas tirar o que é universal. Ele classifica a língua como social, pois depende de convenção, de um acordo entre os indivíduos para poder realizar esse código em sua fala individual - "ela é a parte social da linguagem" (p. 22). Saussure afirma que o estudo da linguagem comporta duas partes: a "social", que é "essencial" e tem como objeto a língua, e a "individual", que é "secundária" e tem por objeto a fala. No entanto, essas duas partes são interdependentes, pois é por meio da fala que a língua evolui e esta é tanto um instrumento quanto um produto daquela. Por isso, ele dividiu esses estudos em Linguística da Língua e Linguística da Fala, em que a língua é o sistema "que conhece somente sua ordem própria" (p. 31); como se trata de um sistema interno, seu estudo deve excluir tudo o que é externo a esse sistema, como a Etnologia e os elementos históricos. Por sua vez, as relações entre a língua, a história política e os costumes de uma nação devem ser focalizados na Linguística externa.

Saussure afirma que o signo linguístico "une não uma coisa e uma palavra, mas um conceito (significado) e uma imagem acústica (significante)" (p. 80). Os seus termos são psíquicos e o conceito faz suscitar no cérebro a imagem acústica (não material) que corresponde a esse conceito. Em seguida, esse processo psíquico (podemos recitar um poema apenas imageticamente sem que enunciemos qualquer som) 
ocasiona fisiologicamente um impulso nos órgãos da fonação, o que gera as ondas sonoras que são propagadas. Assim sendo, os sons da fala são de natureza fisiológica e a fala é um processo pelo qual o indivíduo é responsável, i.e., a fala tem um caráter de significação individual e o som vocal corresponde à palavra "falada".

Saussure adota, para o estudo do signo linguístico, dois princípios: o da "arbitrariedade do signo" e o do "caráter linear do significante" - este último independe da simplicidade desse princípio. $\mathrm{O}$ funcionamento da língua depende dele, quando utiliza a sequência dos signos em forma de cadeia, formando um mecanismo que possibilita a compreensão da língua. Essa relação de caráter linear gera "certa ordem de valores" (p. 142) que corresponde a formas de organização de nossa mente e evita a enunciação de dois elementos simultaneamente. A essas combinações de ordem linear e associativa ele denomina "sintagmas", que representam não só a unidade "palavra", mas também os grupos de palavras (palavras compostas, derivadas, membros de frases). Esses grupos, além de aproximarem entre si os seus termos, estão relacionados significativamente de forma solidária, de acordo com a natureza das relações que seus termos expressam.

Portanto, a arbitrariedade do signo é uma continuidade do estudo acerca da justeza dos nomes. Esse princípio merece uma discussão à parte pela sua complexidade e por ocupar lugar central neste trabalho.

\section{SOBRE A ARBITRARIEDADE}

Whitney retoma a antiga discussão dos gregos acerca da natureza dos nomes das coisas - se esses nomes existem por natureza ou por atribuição/convenção - e afirma que a língua é uma instituição como as outras. Para esse autor, uma palavra não é o reflexo de uma ideia nem sua descrição, nem sua definição, mas a sua designação, um signo "arbitrário e convencional" que nós aprendemos a associar. Por essa razão, não tem força interna conservativa de identidade, estando exposto às mudanças, de acordo com as circunstâncias externas, com as necessidades de uso prático, com a conveniência e o capricho daqueles que o empregam.

Saussure define o signo linguístico como o resultante da associação do significante com o significado e afirma que há total ausência de 
qualquer laço que una esses dois elementos, o que gera o "princípio da arbitrariedade do signo linguístico". Ele ilustra esse princípio mostrando que a ideia (significado) de um nome como, por exemplo, mar não tem nenhuma relação com a sequência dos sons $m-a-r$ (significante). Essa mesma ideia pode ser representada pelos diferentes significantes existentes em outras línguas. Saussure pensa no sistema, não está preocupado com questões de origens das palavras, de motivações dessas; só quer explicar a língua em si mesma, como um sistema. Para ele, depois de o termo estar estabelecido socialmente, cai no uso; é como se o referente não fizesse parte do mundo linguístico - "todo meio de expressão aceito numa sociedade repousa, em princípio, num hábito coletivo ou, o que vem dar na mesma, na convenção" (p. 82). Saussure acrescenta que esse princípio não é contestado por ninguém.

Ao discorrer acerca da arbitrariedade do signo, Saussure reconhece que há signos radicalmente arbitrários, em que o significante não recebe nenhuma motivação, "apenas uma parte dos signos" (p. 152). O significante é escolhido livremente e há signos que são apenas relativamente arbitrários, ou seja, "o signo pode ser relativamente motivado" (p. 152). O autor ilustra esse fato linguístico com os numerais vinte, apresentado como imotivado (arbitrário absoluto), e dezenove, que evoca uma associação de termos como dez, nove, vinte e nove, dezoito etc. Outro exemplo citado como imotivado, pereira " "faz pensar" em cerejeira, macieira etc. Nessa apresentação, ele justifica não ser "esta a ocasião de averiguar os fatores que condicionam, em cada caso, a motivação; mas esta é sempre tanto mais completa quanto a análise sintagmática seja mais fácil e o sentido das subunidades mais evidente" (p. 153). E acrescenta: "mesmo nos casos mais favoráveis, a motivação não é nunca absoluta" (p. 133) - assertivas essas já presentes em "Crátilo".

Depreendemos, pois, que Saussure se refere à essência estrutural de "serem arbitrários" os elementos básicos formadores do sintagma, razão pela qual ele afirma: "não somente os elementos de um signo motivado são arbitrários (cf. dez e nove em dezenove) como também o valor do termo total jamais iguala a soma dos valores das partes; per $\mathrm{X}$ eira não é igual a per + eira" (p. 153). Para ele, os signos inteiramente arbitrários realizam melhor que os outros o ideal do procedimento semiológico, ou seja, de representação dos sistemas de signos. Para justificar o fenômeno da motivação relativa, esse autor sugere que sejam 
observados os seguintes princípios de análise: i) a análise do termo dado, portanto, a relação sintagmática; ii) a evocação de um ou vários termos, portanto, a relação associativa; ou seja, "o mecanismo em virtude do qual um termo qualquer se presta à expressão de uma ideia" (p. 153). Nele fica clara a existência da solidariedade dos termos (de ordem associativa e sintagmática) para expressar significativamente a ideia que a eles se vinculam. Em dezenove há uma aproximação associativa solidária de dezoito, dezessete, vinte, vinte e um (outras formas disponíveis surgem ao redor do signo para nossa escolha; os termos que o rodeiam na cadeia falada) e uma aproximação sintagmática solidária de seus elementos dez e nove (as partes sucessivas que o compõem só têm valor pela sua ação recíproca que forma o todo). Justificando ainda acerca do princípio arbitrário relativo, ele afirma:

[...] com efeito, todo o sistema da língua repousa no princípio irracional da arbitrariedade do signo que, aplicado sem restrições, conduziria à complicação suprema; o espírito, porém, logra introduzir um princípio de ordem e de regularidade em certas partes da massa dos signos, e esse é o papel do relativamente motivado. (p. 154)

Saussure afirma ainda que não existe língua em que nada seja imotivado, assim como não existe língua em que tudo seja motivado, o que há são elementos das duas ordens, radicalmente arbitrário e relativamente motivado. Nesse sentido ele classifica as línguas de dois modos: i) as lexicológicas, em que a imotivação atinge grau máximo; e ii) as gramaticais, em que a imotivação se reduz ao mínimo. Ele afirma que "não há ideias preestabelecidas, e nada é distinto antes do aparecimento da língua" (p. 130). Ou seja, o signo linguístico é fundamental para a clareza das ideias; sem o signo, o pensamento seria uma "nebulosa". O pensamento é, para Saussure, uma abstração feita de sua expressão por meio de palavras, uma massa "amorfa" e indistinta que não se acomoda nos sons. Já os sons são uma matéria plástica que se divide em partes distintas para fornecer os significantes dos quais o pensamento necessita e a língua está marcada pelo plano das ideias e sobre o plano dos sons. O pensamento não necessita materializar-se (assim como o som não necessita espiritualizar-se), mas precisa decompor-se, e é a língua que serve de intermediário entre o pensamento e o som em que este últi- 
mo é utilizado para a fixação das ideias. Como consequência, esse som se torna um signo representante da ideia. A língua seria composta, pois, pelo pensamento e pelo som (significante), em que esses dois últimos elementos estão intrinsecamente unidos: "assim tampouco, na língua, se poderia isolar o som do pensamento ou o pensamento do som" - uma combinação que "produz uma forma, não uma substância" (p. 131).

Saussure justifica, portanto, que esses dois domínios, o do pensamento e o do som (confusos e amorfos), estão ligados pela língua. A escolha feita por tal porção acústica (signo) para uma ideia é arbitrária, pois considera, nessa escolha, a noção de valor (propriedade da palavra, em relação a uma outra, de representar ideias) que ele afirma ser relativa e cuja razão está no uso e no consenso geral, ou seja, na coletividade e não no signo em si. Para exemplificar melhor esse processo, ele cita o exemplo das palavras carneiro, em português, moutton, em francês e sheep, em inglês, que possuem o mesmo significado, mas não o mesmo valor, pois, ao falar de uma porção de carne preparada e servida, o inglês diz moutton e não sheep. Ou seja, sheep tem um segundo termo, moutton, para significar coisa dessemelhante, diferentemente do português e do francês.

Saussure ressalta a necessidade de considerar o termo linguístico não isoladamente, pois dessa forma se desconsideraria não o sistema, mas a totalidade solidária para então proceder à análise dos elementos que ele encerra. Portanto, a arbitrariedade - conforme diz Saussure, que afirma conhecer uma vasta literatura acerca deste assunto - é um princípio que tem sido aceito como verdade para toda a Linguística da língua, desde Platão, Humboldt, Whitney até os sucessores de Saussure. No entanto, é necessário investigar a sua noção de valor, se absoluta ou relativa, ou mesmo nula em determinados sistemas de uma língua.

A seguir analisamos alguns topônimos maranhenses, nos quais discutimos a existência de "justeza natural" ou "convenção" (arbitrariedade).

OS NOMES PRÓPRIOS TOPONÍMICOS: JUSTEZA NATURAL (PHYSEI) OU CONVENÇÃO (THESEI)?

Ao nomear, geramos termos linguísticos produtos de nossas concepções de mundo. Esses termos, os nomes, legitimam social e civil- 
mente a existência de entidades no mundo. Entre as classes de nomes, os próprios caracterizam-se por designar e identificar indivíduos específicos (coisas, lugares, pessoas). Eles mantêm uma relação que lhes dá o caráter de próprio daquilo a que ou a quem se referem; atribuem caráter à coisa identificada, designada pelo nome por meio da evocação desses. Sem o nome, os seres (pessoas, lugares, instituições) se tornam opacos, não delimitados, inexistentes. As expressões que representam os nomes próprios tanto podem ser apenas um nome simples como sintagmas nominais, ou seja, um agrupamento de palavras com ou sem elementos de ligação, ou interligados por elementos gramaticais (artigos, preposições), geralmente um determinante, um nome (sendo este essencial) e um qualificador que se referem aos indivíduos e aos objetos no mundo (CANÇADO, 2008). Entre esses nomes próprios atribuídos há os nomes toponímicos (de lugares), cujo ato denominador se efetua de forma individual e coletiva, simultaneamente, e se fundamenta e se justifica linguisticamente ao concentrar parte da história e da cultura de um povo. Para analisar a natureza dos nomes toponímicos, observamos brevemente a relação sintagmática e associativa dos elementos que os compõem. Por meio da solidariedade dos termos depreendemos a ideia designativa e significativa que eles vinculam, ao contextualizar social, cultural e historicamente esses lugares.

Como exemplos de formas simples temos Alcântara, Viana e Matinha..$^{5}$ As formas simples já trazem em si a essência da referência representada no léxico. O nome próprio com estrutura simples é o próprio índice, carrega consigo o conceito sintético, não proporciona outras relações de determinação, qualificação ou de pertencimento externas que podem ser representadas sintaticamente de maneiras diversas. Portanto, Alcântara carrega consigo o significado da forma simples Alcântara, sem a presença de determinantes, qualificativos ou de termos que indiquem posse. O nome Viana indica uma referenciação ao lago de igual denominação e se refere a alguém ou a algo a quem a comunidade quis homenagear. Matinha também é expresso por forma simples e corresponde ao nome de uma localidade em Portugal. Esses três nomes evidenciam o processo de transplantação cultural, por meio do índice léxico, pois se referenciam a nomes de localidades situadas em Portugal e ou ainda ao nome/sobrenome de algum português ou descendente. 
Os topônimos Brejo e Morros são formados por nomes-núcleos e podem ser considerados modelos prototípicos que representam os nomes dos acidentes geográficos nos quais as cidades se situam ou estão próximas. O nome da cidade de Cajapió designa um antigo aldeamento indígena localizado às margens do igarapé de mesmo nome, o que motivou culturalmente a sua denominação. A origem etimológica é tupi e vem de cajá-pyoca, polpa de cajá, essência de cajá (TiBIRIÇÁ, 1997). Bacuri e Jatobá são nomes-núcleos atribuídos a vegetais bastante comuns nas respectivas cidades a que emprestam o nome.

As formas compostas enunciam relações de interdependência e de solidariedade sintagmática e associativa de acordo com a ordem em que se apresentam e de como se estruturam sintaticamente esses elementos. Por meio do personagem do diálogo "Crátilo", Sócrates, afirmava que, se os elementos explicavam o significado de seus compostos, a justeza desses compostos devia ser a mesma de seus elementos. Saussure, entretanto, demonstra que nem sempre isso se dá tão matematicamente como uma soma. Como formas compostas temos os nomes Alto Parnaiba, Jenipapo dos Vieiras, Matões do Norte, Nova Olinda do Maranhão construídos de forma semelhante. Eles têm como referência o fato de representarem as dimensões dos acidentes geográficos simbólicos desses lugares com o auxílio dos qualificativos que formam o sintagma. Alto Parnaiba tem como referente um rio. Diferentemente dos nomes comuns, a expressão sintagmática descritiva da cidade de Alto Parnaíba traz consigo a informação do nome-núcleo Parnaiba, que é a substância do sintagma que nomeia o rio à margem da cidade. $\mathrm{O}$ qualificativo Alto posiciona o rio e a cidade, localizada numa região alta em relação às demais localidades que o rio percorre. Jenipapo dos Vieiras relaciona sintagmaticamente o nome-núcleo Jenipapo a um grupo humano possuidor de terras naquela região, cuja relação atributiva de posse é motivada cultural e historicamente. Matões do Norte é um nome composto, em que o núcleo expressa a forma topográfica; a preposição de indica pertencimento e o nome qualificativo indica posição geográfica. Nova Olinda do Maranhão faz referência ao indicador cronológico Nova (qualificativo) e à ideia de pertencimento (genitivo) ao estado Maranhão.

Convém ressaltar o fato cultural de muitos nomes toponímicos quer sejam sintagmas simples ou compostos - serem antropotopônimos, pelo costume, em nossas sociedades, de dar aos lugares nomes de 
pessoas bem conhecidas, como também o de títulos atribuídos a essas pessoas. Em Bequimão, Caxias e Guimarães, as formas simplificadas denotam pessoas nacionalmente reconhecidas, no caso dos dois primeiros exemplos. O último exemplo refere-se ao nome de uma pessoa que também já foi atribuído a uma cidade em Portugal. No sintagma nominal Benedito Leite há o nome Benedito, que é o "prenome", dado a alguém quando nasce, na cerimônia do batismo ou em outra ocasião específica, de acordo com a cultura e os costumes de cada povo, e denota o indivíduo Benedito. É por esse nome que a pessoa geralmente passa a ser conhecida e chamada; é o nome de batismo ou antenome. Há o "sobrenome" Leite, que é a palavra que se agrega ao prenome para denotar a origem do sujeito Benedito, para indicar o nome de família deste, quem é pai, qual o clã e os antepassados desse (HouAIss \& VILLAR, 2001).

Da mesma forma que o nome denota o indivíduo, o sobrenome o faz também pertencente a uma classe de indivíduos. O nome Governador Eugênio Barros, além desses elementos, traz consigo o nome que indica um título honorífico atribuído a essa pessoa como "governador", o que o caracteriza como líder de uma comunidade e, provavelmente, é o instrumento que lhe fez render a homenagem dessa comunidade denominadora. Em São Raimundo do Doca Bezerra há uma complexidade cultural extensa que envolve o ato denominador, por meio da expressão definida descritiva. O primeiro nome São (apócope de santo) indica alguém que foi canonizado e nos reporta à religiosidade tão presente na cultura maranhense. A expressão genitiva do Doca Bezerra caracteriza o nome São Raimundo como pertencente a esse personagem. São, pois, duas nomeações representadas numa só expressão: a primeira nomeia a cidade de São Raimundo, e a segunda, a cidade de São Raimundo como sendo do Doca Bezerra.

Em todos esses topônimos fica clara a intenção de tornar permanente uma identidade cultural de uma outra entidade - humana - ao definir uma entidade geográfica. Esses nomes fazem entrecruzar a relação de existência geográfica e humana, pela atribuição de nomes descritivos próprios da espécie humana para a espécie geográfica, num processo quase de antropomorfização, além da identificação genitiva em que uma cidade passa a ser a cidade de Bequimão, a cidade de Benedito Leite, ou de Governador Eugênio Barros. Acerca dessas formas de 
representação, convém observar esses topônimos representados em grande quantidade como nomes próprios que definem uma identidade por meio de uma outra identidade já existente. Segundo Lévi-Strauss (2008), o espaço é uma sociedade de lugares nomeados da mesma forma que as pessoas são pontos de referência dentro de um grupo. Assim, os lugares e os indivíduos são designados da mesma forma por nomes próprios em que esses nomes podem ser substituídos uns pelos outros.

Como último exemplo, Balsas é apenas e simplesmente o nome escolhido que representa um elemento cultural para representar civilmente essa cidade. Mas, por que Balsas e não Barco ou Canoa ou outro nome qualquer? A denominação é motivada e se deve ao tipo de embarcação bastante usada no rio - do mesmo nome - que banha a cidade. Ou seja, dificilmente essa cidade teria como nome os signos "barco" ou "canoa", posto que esses elementos culturais surgem em outro plano que não o primeiro, conforme ocorre com o elemento cultural "balsas".

Depreendemos, dessa forma, que a arbitrariedade do signo não se aplica a todos os sistemas da língua portuguesa, posto que o sistema denominador toponímico não é tão arbitrário. Esse sistema recebe motivações que são contextualizadas social, cultural e historicamente em relação ao sujeito denominador e se tornam aparentes no vocabulário da língua. Os nomes próprios são, pois, associados aos seres que eles denotam e nomeiam. Essa representação não involuntária relaciona, por meio do sistema linguístico, o signo (significante/significado) à sua representação mental das coisas do mundo; ou seja, há motivação nesse processo denominador. Os nomes das cidades maranhenses lembram o significado de algo ou de alguém e o relacionam ao espaço que lhes dá a ideia de pertencimento. Balsas tanto nos lembra o nome do rio que banha a cidade como o meio de transporte outrora e ainda usado nesse rio navegável. Portanto, tendo como base esses exemplos, na morfologia onomástica a toponímia é, sem dúvida, um sistema em que ocorre o fenômeno da "motivação linguística" ou da "arbitrariedade nula" e isso se dá de forma tão premente exatamente para contextualizar esses nomes. Afinal esta também é uma das funções da linguagem. Não há dúvidas acerca do princípio da arbitrariedade do signo e, no conjunto dos nomes comuns primitivos, esse princípio é ainda mais verificável. 
No entanto, no que diz respeito aos nomes próprios, principalmente os toponímicos, a arbitrariedade é bastante tênue e o que prevalece é o processo motivador da escolha dos nomes.

Há, portanto, nomes que são instituídos de forma motivada, o que postularam Saussure e Whitney apenas timidamente para o signo linguístico. No caso dos nomes próprios toponímicos, estes são exemplos singulares de quão forte se dá esse processo de instituição no sistema denominador.

\section{CONSIDERAÇõES FINAIS}

Diante do exposto, os estudos aqui focalizados centraram-se na interface da Linguística historiográfico-estrutural e antropológica dos nomes, fazendo uma correlação dessas teorias com os nomes próprios toponímicos maranhenses.

Iniciamos com o diálogo "Crátilo", de Platão, em cujo início Sócrates defende a tese naturalista apresentada por Crátilo em que, no caráter de formação natural da linguagem, o conteúdo e a forma se ligam por justeza natural (Physei). No Episódio 2, com Crátilo, Sócrates revê essa postura e admite a tese convencionalista defendida por Hermógenes em que aquele aceita certo grau de convenção no ato de nomear (Thesei).

Whitney e Saussure, por sua vez, recuperam a obra platônica e se posicionam firmemente em favor da convencionalidade do signo. Saussure considera que o signo linguístico é arbitrário, não mantendo nenhuma relação entre o significante e o significado. No entanto, no Capítulo VI, ele pondera essas colocações e classifica o signo como "arbitrário absoluto" (aquele que não possui nenhuma motivação) e "arbitrário relativo" (aquele que é relativamente motivado, ou seja, tem como característica não ser jamais completamente arbitrário). Whitney também assume essa postura atenuada acerca da arbitrariedade do signo.

$\mathrm{Na}$ análise dos nomes de algumas cidades maranhenses, verificamos que, além dos fatores intrínsecos à língua, os fatores históricos, sociais e culturais são fundamentais na estruturação do sistema denominador toponímico. Isso influencia no processo de motivação para a atribuição desses nomes e nem sempre ocorre com outras classes de nomes. 
Conforme sugere Lévi-Strauss (2008), nomear é um procedimento de escolha que identifica o indivíduo como pertencente a uma classe. Assim, podemos observar, a partir de uma base antropológica, que o signo nunca é absolutamente arbitrário, mas social, cultural e historicamente motivado. Basta observar como as estruturas morfossintagmáticas utilizadas para designar os referentes "cidades do Maranhão" possuem estruturas de acordo com a gramática da língua dessas comunidades e encapsulam as diversas motivações inerentes ao processo denominador de um grupo instituído e distribuído, como já dissemos, social, cultural e historicamente, de acordo com suas experiências e visão de mundo.

Podemos dizer ainda que toda a teoria acerca da natureza dos nomes, apresentada por Platão, se Physei ou Thesei, deu impulso a uma grande diversidade de estudos em diversas áreas do conhecimento que pesquisam a linguagem. Esses saberes clássicos legados a seus posteriores receberam apenas algumas modificações que foram acrescentadas principalmente na área das ciências linguísticas, de um modo específico, nos estudos histórico-comparatistas, influenciados pelas ideias do romantismo, em que este retomava os valores do classicismo. Portanto, vemos claramente a continuidade dos conhecimentos platônicos em outros tantos que marcaram e ainda marcam a história dos estudos linguísticos, como nos escritos comparatistas de Whitney e no Curso, de Saussure, este também com formação romântica. Muitos autores dessa época eram falantes fluentes das línguas clássicas, o que por si só justifica a influência dessa cultura nesses estudos. Também receberam influência da obra platônica os textos filosóficos de Wittgenstein e a antropologia de Lévi-Strauss; na Linguística Moderna, essa influência é perceptível na teoria dos atos de fala, de Austin, na teoria funcionalista da linguagem, na pragmática, na semiótica, na história da linguagem, na fonética, na morfologia. Nesta, os ensinamentos platônicos trazem uma grande contribuição para os estudos onomásticos e, de modo aqui particularizado, para a toponímia. Enfim, tanto Platão quanto Whitney e Saussure ainda estão muito presentes nas orientações linguísticas e filosóficas atuais com o grande conhecimento que nos legaram. Convém reconhecer também que esses estudiosos deixaram muitas lacunas para que continuássemos essas pesquisas. 
In this paper, we use classical theory about the nature of names and discuss in a historiographical way the philosophical thoughts that began these studies, starting from the Platonists in "Cratylus", through Whitney's discussion up to the always contemporary studies of Saussure. These authors discuss if the names are formed by natural justice (Physei) or by convention (Thesei). We relate this discussion to the toponymical names in the municipalities of Maranhão state. We then inter-relate the influence of the formal structure of the linguistic sign to the object that it represents in the process of naming.

KEY WORDS: names, natural justice, convention, maranhense, toponyms.

\section{Notas}

1 "Método socrático que consiste na multiplicação de perguntas, induzindo o interlocutor na descoberta de suas próprias verdades e na conceituação geral de um objeto" (Houaiss \& VILLAR, 2001, p. 1814).

2 A tradução das citações de Whitney foi feita pelas autoras deste artigo.

3 Sugerimos a leitura da tese de doutoramento do Prof. Dr. Sebastião Elias Milani, incluída nas referências deste trabalho.

4 Conforme assertiva enunciada pelo Prof. Dr. Sebastião Elias Milani, em sua aula de 22 de agosto 2008. A propósito, muito do que aqui escrevemos foi inferido a partir das aulas desse professor, a quem agradecemos.

5 Esses exemplos e os que se seguem foram retirados do artigo inédito de Castro (1998).

\section{REFERÊNCIAS}

CAnçado, M. Manual de semântica: noções básicas e exercícios. Belo Horizonte: Ed. UFMG, 2008.

CAstro, M. C. D. de. O papel da referência e da classificação prototípica na formação toponímica dos municípios maranhenses. Goiânia, 2008. Texto inédito.

Houaiss, A.; Villar, M. de S. Dicionário Houaiss da Língua Portuguesa. Rio de Janeiro: Objetiva, 2001. 
LÉvi-Strauss, C. O pensamento selvagem. São Paulo: Papirus, 2008.

Milani, S. E. Humboldt, Whitney e Saussure: romantismo e cientificismosimbolismo na história da Linguística. 2000. Tese (Doutorado em Linguística) - Universidade de São Paulo, São Paulo, 2000.

Platão. Os diálogos de Platão. Tradução de Carlos Alberto Nunes. v. IX: Teeteto - Crátilo. Belém: Editora UFP, 1973.

Saussure, F. Curso de linguística geral. 20. ed. São Paulo: Cultrix, 1995. [1. ed. 1916].

TiBiriçÁ, L. C. Dicionário de topônimos brasileiros de origem tupi: significado dos nomes geográficos de origem tupi. São Paulo: Traço, 1997.

Whitney, W. Dwight. Whitney on language: selected writings of William Dwight Whitney. Cambridge: The MIT Press, 1971. [1. ed. 1871]. 